\title{
A Case of Congenital Chylous Ascites and Hypothyroidism: Coincidence or Association?
}

\section{Konjenital Şilöz Asit ve Hipotiroidi Olgusu: Tesadüf mü, Birliktelik mi?}

(1) Özgül Bulut, (1) Emine Asuman Çoban, (1) Zeynep İnce

\section{ABSTRACT}

Congenital chylous ascites (CA) is the rare accumulation of chyle in the peritoneal cavity, often occurring in infants under three months of age. In this case study, we report a case of congenital CA detected prenatally on routine 34-week fetal ultrasound in the presence of congenital hypothyroidism. Treatment consisting of thyroid hormone supplementation, a diet high in middle-chain triglycerides and octreotide administration was undertaken. To our knowledge, this is the second case of CA in the presence of congenital hypothyroidism described in the literature.

Keywords: Congenital chylous ascites; hypothyroidism; newborn; octreotide.

Department of Pediatrics, Division of Neonatology, Istanbul University Istanbul Faculty of Medicine, Istanbul, Turkey

Cite this article as: Bulut Ö, Çoban EA, Ince Z. A Case

of Congenital Chylous Ascites and Hypothyroidism: Coincidence or Association?

Bosphorus Med J

2020;7(3):102-105.

Received: 08.07.2020 Accepted: 04.08.2020

Correspondence: Dr. Özgül Bulut. İstanbul Üniversitesi İstanbul Tıp Fakültesi Neonatoloji Anabilim Dalı, Çocuk Sağlığı ve Hastalıkları Anabilim Dalı,

İstanbul, Turkey

Phone:

+905057502536

e-mail:

ozgulbulut@yahoo.com

OPEN ACCESS

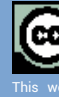

\section{ÖZET}

Konjenital şilöz asit (ŞA), şilözün nadiren periton boşluğunda birikimidir ve genellikle üç aylıktan küçük bebeklerde görülür. Bu yazıda, konjenital hipotiroidizm varlığında 34 haftalık rutin fetal ultrasonda prenatal olarak saptanan konjenital ŞA olgusu sunulmuştur. Tiroid hormon takviyesi, yüksek orta zincirli trigliseritlerden oluşan bir diyet ve oktreotid uygulamasından oluşan tedavi uygulandı. Bildiğimiz kadarıyla, bu literatürde tanımlanan konjenital hipotiroidizm varlığında ikinci ŞA olgusudur.

Anahtar sözcükler: Hipotiroidizm; konjenital şilöz asit; oktreotid; yenidoğan.

ongenital chylous ascites (CA) is characterized by the accumulation of chyle in the peritoneal cavity of infants under three months of age. CA is a rare disorder of lymphatic vessel development seen in the newborn period. ${ }^{[1]} \mathrm{Ge}$ netic factors play a significant role in CA etiology and pathogenesis. ${ }^{[2]}$ Currently, identifiable causes, such as lymphatic obstruction, lymphangiomatosis, or atresia of the lymphatic system, are only identified in $50 \%$ of patients. Delayed maturation of lacteals and leakage of chyle into the peritoneal cavity due to a phenomenon known as leaky lymphatics are believed responsible for this condition. ${ }^{[3]}$
The signs and symptoms of congenital CA are nonspecific and include vomiting, increased abdominal circumference, abdominal distention, poor feeding, scrotal or vaginal swelling, inguinal hernia, and symptoms of respiratory failure. ${ }^{[1]}$ Imaging modalities that reveal fluid, such as ultrasonography (USG) and computerized tomography, help rule out other causes and paracentesis confirms the diagnosis. Conservative treatment modalities, such as fasting, total parenteral nutrition (TPN), high-protein low-fat diets with medium-chain triglycerides (MCT), and abdominal paracentesis are preferred initially. Treatment with somatostatin analogs has 
been reported in a limited number of infants. ${ }^{[1-4]}$ Diagnosis of congenital hypothyroidism, which can present with ascites, is commonly made using newborn screening. ${ }^{[5,6]}$

In this case report, we discuss the occurrence of congenital CA and congenital hypothyroidism in a newborn successfully treated with TPN, MCT, and octreotide.

\section{Case Report}

A female infant was born to a 28-year-old G2P1 mother by cesarean section at 38 weeks four days gestation; the birth weight was $3800 \mathrm{~g}$. The parents were non-consanguineous and had previously given birth to a healthy male. A routine antenatal USG at 34 weeks gestation revealed polyhydramnios and fetal ascites. Prenatally, $740 \mathrm{~mL}$ of fluid was removed at 34 weeks, and another $500 \mathrm{~mL}$ was removed at 38 weeks gestation. At birth, the baby had mild respiratory distress without the need for ventilator support. Apgar scores were seven and eight at one and five minutes postnatally, respectively. Oxygen saturation was $93 \%$ on room air, and the umbilical cord blood gas analysis revealed a $\mathrm{pH}$ of $7.32, \mathrm{pCO}_{2}$ of $45.8 \mathrm{mmHg}$, and base excess of $-4 \mathrm{mmol} / \mathrm{L}$. The baby was transferred to the neonatal intensive care unit for respiratory distress and fetal ascites. No dysmorphic features were present, and the karyotype analysis was normal. Congenital infections, such as cytomegalovirus and T. gondii, metabolic disorders, and genetic syndromes, were all excluded from this study. Routine hematologic and biochemical parameters were normal. Thyroid function tests revealed free (f) T4 of $10.8 \mathrm{pmol} / \mathrm{L}$ (normal range: 11.6-33.5) and a thyroid-stimulating hormone (TSH) level of $22.9 \mathrm{mIU} / \mathrm{L}$ (normal range: 0.9-7.7). Levothyroxine treatment was initiated as a result of these findings. Postnatal USG revealed no thoracic effusion but showed $18 \mathrm{~mm}$ of hypoechoic fluid in the hepatorenal pouch, $33 \mathrm{~mm}$ of fluid in the hepatosplenic pouch, and 7 $\mathrm{mm}$ of fluid in the lower abdomen. Portal Doppler USG and upper gastrointestinal study with contrast material revealed no pathology. Echocardiography confirmed a patent ductus arteriosus and a patent foramen ovale.

The infant's respiratory distress settled over the next few days following continuous positive airway pressure therapy. The patient was breastfed and discharged at postnatal day 10 , as no increase in the ascitic fluid was evident, and the abdominal girth of $41.5 \mathrm{~cm}$ remained constant. Four days later, the patient was readmitted with fever, abdominal distension, and irritability. Abdominal girth had increased to $45 \mathrm{~cm}$ (Fig. 1). Laboratory examinations of serum

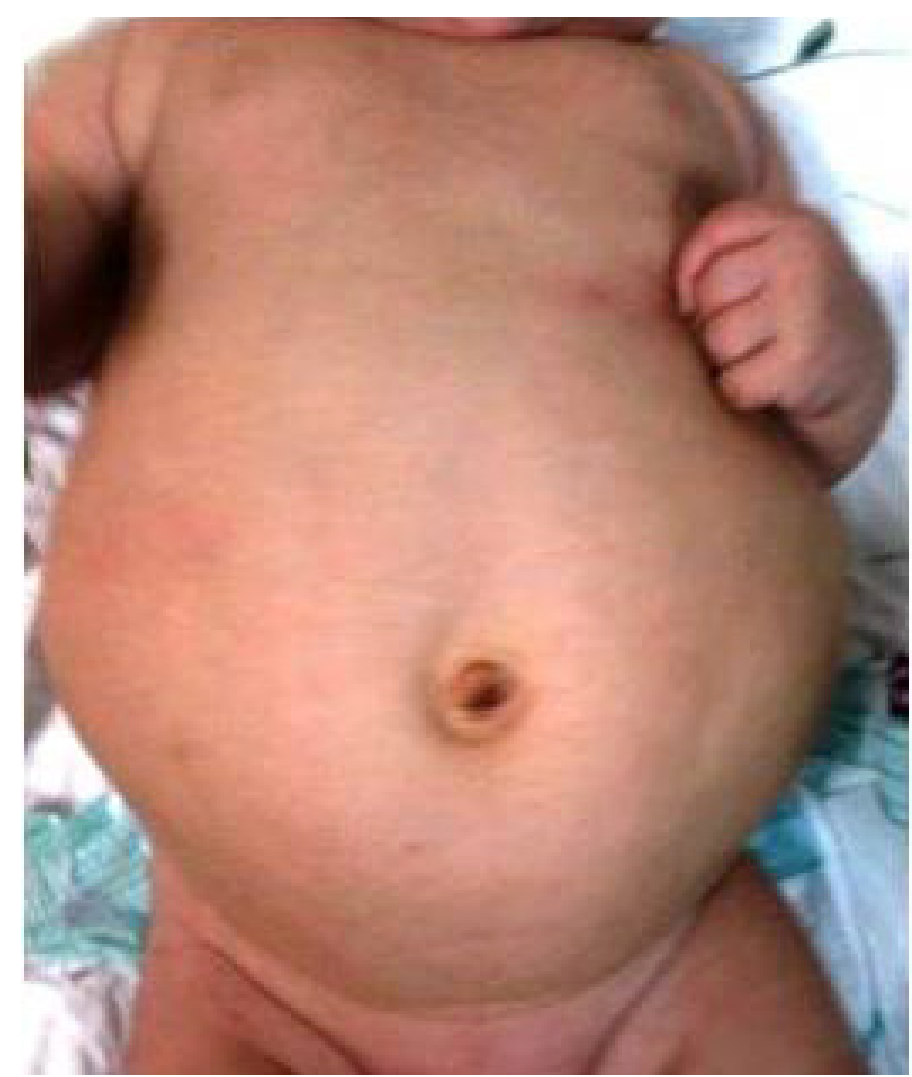

Figure 1. Increased abdominal girth of infant.

electrolytes, liver function, and renal function were within normal limits, except for an increase in C-reactive protein $(48.6 \mathrm{mg} / \mathrm{L})$ and an abnormal complete blood count showing leukopenia (white blood cell count: $4220 / \mathrm{mm}^{3}$; neutrophil count: $1630 / \mathrm{mm}^{3}$; lymphocyte count: $1280 / \mathrm{mm}^{3}$; platelet count: $250 \times 10^{3} / \mathrm{mm}^{3}$ ). Abdominal paracentesis yielded $250-300 \mathrm{~mL}$ of cloudy yellow ascitic fluid, which contained 4010 cells/mL (90\% lymphocytes), $3.3 \mathrm{~g} / \mathrm{dL}$ of protein, $2.6 \mathrm{~g} / \mathrm{dL}$ of albumin, an LDH of $273 \mathrm{IU} / \mathrm{L}, 508 \mathrm{mg} /$ $\mathrm{dL}$ of triglycerides (Normal range: 30-100), and $89 \mathrm{mg} / \mathrm{dL}$ of glucose (Fig. 2). Cytological examination revealed no

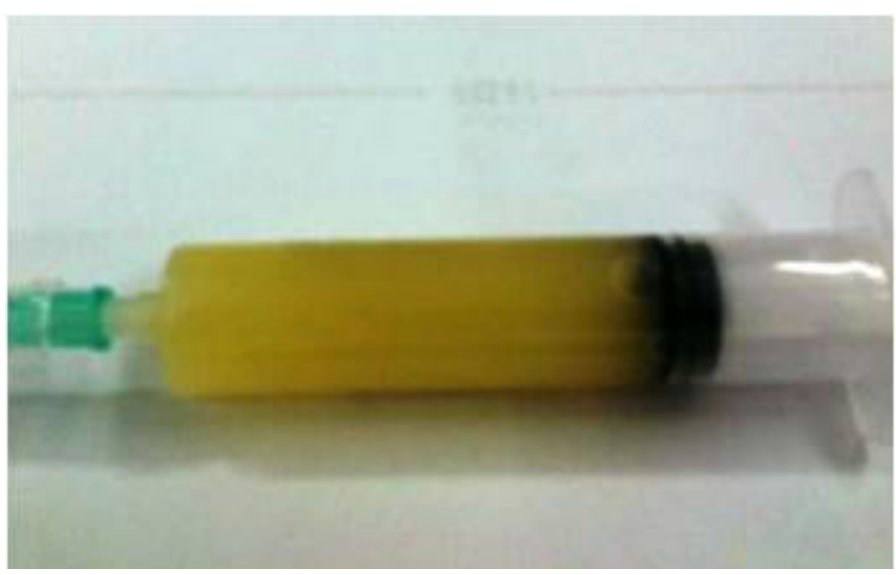

Figure 2. Appearance of aspirated abdominal fluid. 
atypical cells, and bacterial cultures were negative. These findings led to a diagnosis of sepsis, congenital CA, and congenital hypothyroidism in this infant. Etiological evaluation by CT scan revealed no other pathology, such as mesenteric cysts or lymphatic malformations. Upper gastrointestinal endoscopy and biopsy revealed no abnormalities. In addition to antibiotic treatment, TPN was started due to the infant's intolerance of the MCT-rich formula. Volume and electrolyte hemostasis were maintained while proteins, coagulation factors, and immunoglobulins were replaced as needed. Following two weeks of therapy, sepsis markers returned to baseline, antibiotics were stopped, and blood cultures showed no bacterial growth. Enteral feeding was reintroduced, and treatment with octreotide (Sandostatin ${ }^{\circledR}$, Novartis) was initiated ( $3 \mu \mathrm{g} / \mathrm{kg} / \mathrm{hour}$, intravenously), as there had been no reduction in the volume of ascites. However, ascitic fluid continued to accumulate even after the introduction of octreotide and palliative paracentesis. The dose of octreotide was increased to $8 \mu \mathrm{g} /$ $\mathrm{kg} /$ hour during the next 14 days, which led to a decrease in abdominal girth. USG confirmed a regression of ascites to near-normal levels. No overt side effects of octreotide treatment were observed, and full enteral feeding with a fat-free formula containing 50\% MCT (Basic-P) was established over the ensuing two weeks. The infant was discharged on the MCT feeding regimen, octreotide subcutaneously (8 $\mu \mathrm{g} / \mathrm{kg} /$ day), and thyroid hormone supplementation (thyroid hormone levels at discharge: fT4: $1.8 \mathrm{pmol} / \mathrm{L}$; TSH: $13.1 \mathrm{ml}$ U/L). Follow-up abdominal USG showed no change in the amount of ascites, so subcutaneous octreotide treatment was continued. Following eight months of octreotide treatment, the ascites resolved, and octreotide treatment was gradually discontinued. With continuing levothyroxine treatment, the growth and development of the patient 10 months postnatally were normal. The patient's consent was obtained for this case report.

\section{Discussion}

Congenital CA is often refractory to therapy, which may lead to anemia, hypoproteinemia, hypocalcemia, hyperlipidemia, immunocompromise, and malnourishment due to a chronic loss of proteins and lymphocytes in the chyle, which mandates prompt diagnosis and treatment. ${ }^{[1,3]}$

Diagnosis of the chylous effusion is dependent on finding a body fluid with a milk-like appearance, a concentration of triglycerides greater than $1.1 \mathrm{mmol} / \mathrm{L}$, and a total cell count greater than 1000 cells/mL, with a predominance of lymphocytes ( $>80 \%)$. Fluid having a milky appearance and the presence of chylomicrons with a positive Sudan III test are diagnostic in orally fed infants. The appearance of chyle depends on its composition, cellular constituents, and diet. Although lymphangiography is the gold standard for diagnosis, lymphoscintigraphy and lymphangiography have been avoided in newborns and infants due to their technical difficulty and side effects. ${ }^{[2]}$

The goal of conservative treatment is to provide gut rest while decreasing intestinal secretions. ${ }^{[4]}$ Surgical intervention is recommended in cases that are refractory to conservative management. ${ }^{[4]}$ Somatostatin analogs have been used for CA, especially following a failed conservative approach. Although the exact mechanism of action is not well understood, it has been suggested that somatostatin analogs decrease the production of chyle by reducing the absorption of fatty acids from the intestine, decreasing secretions from the stomach and pancreas, and decreasing intestinal motility and visceral blood flow. ${ }^{[3,4]}$ Somatostatin analogs also inhibit specific receptors found in lymphatic vessels of the intestinal wall, which results in decreased excretion of lymph. ${ }^{[3,7]}$ Although some investigators have reported the successful use of octreotide in congenital CA, ${ }^{4}$, 8] others have demonstrated octreotide to be inadequate even at a maximum intravenous (IV) dose of $10 \mu \mathrm{g} / \mathrm{kg} / \mathrm{h}$. ${ }^{[9]} \mathrm{A}$ study conducted by Huang et al. ${ }^{[4]}$ used octreotide at $1.5 \mu \mathrm{g} /$ $\mathrm{kg} / \mathrm{h}$ IV for 10 days, whereas other studies used octreotide at an initial dose of $0.5 \mu \mathrm{g} / \mathrm{kg} / \mathrm{h} \mathrm{IV}$, gradually titrated to $2 \mu \mathrm{g} /$ $\mathrm{kg} / \mathrm{h}$ for nine days. ${ }^{[8]}$ In our case, octreotide was started at $3 \mu \mathrm{g} / \mathrm{kg} / \mathrm{h}$ and increased to $8 \mu \mathrm{g} / \mathrm{kg} / \mathrm{h}$ following unresponsiveness to lower doses. The advantages of somatostatin analogs include their ease of administration, noninvasiveness, high efficacy, short duration of treatment and a short length of hospital stay. ${ }^{[1,4,7,8]}$

Rare side effects of octreotide include the potential to develop necrotizing enterocolitis and pulmonary hypertension. ${ }^{[8]}$ Maayan-Metzger et al. ${ }^{[10]}$ offered a case report of an infant treated with somatostatin who later developed primary transient hypothyroidism.

Congenital CA was present alongside congenital hypothyroidism in our case. The question that arises is whether fetal hypothyroidism can lead to CA. The effects of thyroid hormone are known to be mediated by adrenergic receptors, ${ }^{[6]}$ and it is hypothesized that thyroid hormone deficiency causes reduced adrenergic stimulation of the lymphatic system. 
This could result in a sluggish flow of the lymph, engorgement of the lymphatic system, and leakage of lymph into the peritoneal cavity, which may lead to CA.

Hypothyroidism in fetal rats causes a reduction in the number of alpha-1 receptors in the kidneys. ${ }^{[11]}$ Thyroid hormone is known to exert a positive inotropic effect on the primate heart by upregulating beta- 1 and, particularly, beta-2 adrenergic receptors. ${ }^{[12]}$ Animal studies demonstrate a direct relationship between the rate of lymphatic flow and lung liquid clearance with adrenergic receptor activity in the lymphatic system. Intracoronary infusion of a beta-agonist in dogs led to an increase in lymphatic flow and protein efflux into the lymph. ${ }^{[13]}$

The association of congenital hypothyroidism and congenital chylothorax has been described in the literature. ${ }^{[6,14]}$ We found no report of a similar association between congenital hypothyroidism and CA. However, a single previous case report has described a case of CA accompanied by congenital hypothyroidism, which resolved following thyroid hormone supplementation, octreotide treatment, and a diet containing MCT. ${ }^{[15]}$

\section{Conclusion}

Congenital CA is a rare disease whose pathogenesis and treatment are poorly understood. No underlying cause was identified in this case, and it is possible that the primary malformation of the lymphatic veins may have been responsible for CA. Significant improvement in the ascites was only observed after all of the recommended treatments for CA (TPN, MCT-formula, and octreotide) were implemented, in combination with thyroid hormone replacement. When considering the role of thyroid hormones in the regulation of adrenergic receptors in the lymphatic system, it is unclear whether congenital hypothyroidism in our patient was a mere coincidence or a direct or perpetuating cause of CA.

\section{Disclosures}

Informed consent: Written informed consent was obtained from the patient for the publication of the case report and the accompanying images.

Peer-review: Externally peer-reviewed.

Conflict of Interest: None declared.
Authorship Contributions: Concept - Ö.B.; Design - Z.I.; Supervision - E.A.Ç.; Materials - Ö.B.; Data collection \&/or processing - Ö.B.; Analysis and/or interpretation - Ö.B., Z.i.., E.A.Ç; Literature search - Ö.B.; Writing - Ö.B.; Critical review - Z.I.., E.A.Ç.

\section{References}

1. Romańska-Kita J, Borszewska-Kornacka MK, Dobrzańska A, Rudzińska I, Czech-Kowalska J, Wawrzoniak T. Congenital chylous ascites. Pol J Radiol 2011;76:58-61.

2. Karagol BS, Zenciroglu A, Gokce S, Kundak AA, Ipek MS. Therapeutic management of neonatal chylous ascites: report of a case and review of the literature. Acta Paediatr 2010;99:130710. [CrossRef]

3. Mouravas V, Dede O, Hatziioannidis H, Spyridakis I, Filippopoulos A. Diagnosis and management of congenital neonatal chylous ascites. Hippokratia 2012;16:175-80.

4. Huang Y, Xu H. Successful treatment of neonatal idiopathic chylous ascites with total parenteral nutrition and somatostatin. HK J Paediatr 2008;13:130-34.

5. American Academy of Pediatrics, Rose SR; Section on Endocrinology and Committee on Genetics, American Thyroid Association, Brown RS; Public Health Committee, et al. Update of newborn screening and therapy for congenital hypothyroidism. Pediatrics 2006;117:2290-303. [CrossRef]

6. Kessel I, Makhoul IR, Sujov P. Congenital hypothyroidism and nonimmune hydrops fetalis: associated? Pediatrics 1999;103:E9.

7. Bellini C, Ergaz Z, Radicioni M, Forner-Cordero I, Witte M, Perotti G, et al. Congenital fetal and neonatal visceral chylous effusions: neonatal chylothorax and chylous ascites revisited. A multicenter retrospective study. Lymphology 2012;45:91-102.

8. Huang Y, Zhuang S, Li Y, Liu M, Chen H, Du M. Successful management of congenital chylous ascites in a premature infant using somatostatin analogue. Indian J Pediatr 2011;78:345-7.

9. te Pas AB, vd Ven K, Stokkel MP, Walther FJ. Intractable congenital chylous ascites. Acta Paediatr 2004;93:1403-05. [CrossRef]

10. Hruz P, Hirsch HH, Zeller A. A small virus among the large. Praxis (Bern 1994) 2005;94:785-7. [CrossRef]

11. Tan JP, Seidler FJ, Schwinn DA, Page SO, Slotkin TA. A critical period for the role of thyroid hormone in development of renal alpha-adrenergic receptors. Pediatr Res 1997;42:93-102.

12. Hoit BD, Khoury SF, Shao Y, Gabel M, Liggett SB, Walsh RA. Effects of thyroid hormone on cardiac beta-adrenergic responsiveness in conscious baboons. Circulation 1997;96:592-8.

13. Saito D, Hasui M, Shiraki T, Kono H. Effects of coronary blood flow, myocardial contractility and heart rate on cardiac lymph circulation in open-chest dogs. Use of direct cannulation method for subepicardial lymph vessel. Arznneimittelforscung 1997;47:119-24.

14. Kollef MH. Recalcitrant chylothorax and chylous ascites associated with hypothyroidism. Mil Med 1993;158:63-5. [CrossRef]

15. Altunhan H, Annagür A, Ertuğrul S, Yüksekkaya HA, Ors R. Coexistence of Congenital Chylous Ascites and Congenital Hypothyroidism: Case Report. J Med Sci 2012;32:1486-89. [CrossRef] 